\title{
Analisis Alur Proses Pengelolaan Linen Kotor Pada Instalasi Laundry di BLUD RS Sekarwangi
}

\section{Analysis of the Flow Process on Dirty Linen Management at BLUD Sekarwangi Hospital's Laundry Installation}

\author{
H. Djadjang A*, Teguh Wiyono*, Dini Agustiani* \\ *RS Sekarwangi, Sukabumi, Jawa Barat \\ dr.dinie86@gmail.com
}

\begin{abstract}
ABSTRAK
Manajemen laundry dan linen merupakan salah satu indikator dalam penilaian akreditasi rumah sakit. Hasil penelitian pendahuluan ditemukan adanya kenaikan insidensi infeksi daerah operasi pada bulan September-November tahun 2016 dengan bulan September- November tahun 2017 yaitu sebesar 11.3\%. Angka ini lebih tinggi bila dibanding dengan standar kejadian infeksi daerah operasi dari DEPKES yaitu sebesar 2\%. Tujuan penelitian ini adalah untuk menganalisis manajemen pengelolaan linen di instalasi laundry BLUD RS Sekarwangi tahun 2018. Desain penelitian yang digunakan adalah kualitatif. Penelitian dilakukan di BLUD RS Sekarwangi pada April-Juni 2018. Informan penelitian ini ditentukan berdasarkan purposive sampling. Pengumpulan data dengan metode wawancara mendalam, Focus Grup Discussion, observasi dan telaah dokumen. Hasil penelitian dari aspek input kebijakan sudah ada, tenaga belum mencukupi, untuk sarana prasarana dan konstruksi bangun ruang, personal hygiene masih ada belum sesuai standar Kepmenkes. Aspek process tahap pengumpulan belum memisahkan linen infeksius dan non infeksius dan belum ada pencatatan, tahap penerimaan belum ada pencatatan dan linen belum di pisahkan, tahap pengangkutan linen infeksius dan non infeksius belum dipisahkan, tahap pencucian tidak adanya penimbangan, lemari terbuka pada tahap penyimpanan.
\end{abstract}

Kata Kunci: Laundry; Pengelolaan Linen; Rumah Sakit.

\begin{abstract}
Management of laundry and linen is one indicator in the assessment of hospital accreditation. The results of the preliminary study found an increase in the incidence of surgical area infections in September-November 2016 with September-November 2017 which was $11.3 \%$. This figure is higher than the standard incidence of infection of the operating area of the Ministry of Health, which is $2 \%$. The purpose of this study was to analyze linen management at the BLUD Sekarwangi Hospital laundry installation in 2018. The research design used was qualitative. The study was conducted at the Sekarwangi Hospital BLUD in April-June 2018. The informants of this study were determined based on purposive sampling. Data collection by in-depth interviews, Focus Group Discussion, observation and document review. The results of the research from the aspect of policy input already exist, there is insufficient labor, for infrastructure facilities and construction of space, personal hygiene still does not meet the standards of the Minister of Health. The process aspect of the collection stage has not separated the infectious and non-infectious linen and there has been no record, the recording stage has not yet been recorded and the linen has not been separated, the transport of infectious and non-infectious linen has not been separated, the washing stage has no weighing, the cabinet is opened at the storage stage.
\end{abstract}

Keywords: Laundry; Management of Linen; Hospital. 


\section{PENDAHULUAN}

Laundry di berbagai instansi pelayanan kesehatan termasuk rumah sakit, memainkan peranan penting dalam pengendalian penularan infeksi karena selama pasien di rawat di rumah sakit pasien terekspos peralatan laundry dari rumah sakit seperti baju pegawai, perlengkapan tidur, handuk, baju pasien, perlengkapan operasi dan lain sebagainya (Tinker: 2010). Hal ini dipertegas oleh Healthcare Laundry Accreditation Councyl (HLAC, 2011) bahwa saat ini laundry rumah sakit tidak hanya berperan sebagai pemenuhan kebutuhan linen sehari-hari bagi pasien dan tenaga kesehatan tetapi juga sangat berperan penting dalam upaya pencegahan dan kontrol penularan penyakit pada pasien, sehingga peningkatan standar kinerja unit laundry rumah sakit juga akan meningkatkan upaya pencegahan penularan penyakit pada pasien. Unit laundry harus ditangani secara professional dalam rangka penerapan strategi pencegahan infeksi nosokomial.

Seiring dengan tuntutan masyarakat yang semakin kritis dalam memberikan pelayanan kesehatan khususnya pada penderita dan tenaga kesehatan rumah sakit, diperlukan perhatian khusus bagi manajemen dan pimpinan BLUD RS Sekarwangi untuk meningkatkan mutu pelayanan kesehatan yang akan berdampak pada kualitas dan citra rumah sakit, salah satunya adalah pada Instalasi Penunjang Medik BLUD RS Sekarwangi khususnya Instalasi Laundry. Indikator mutu dalam manajemen linen sesuai dengan Standar Pelayanan Minimal Rumah Sakit Tahun 2008 adalah tidak adanya kejadian linen yang hilang dan ketepatan waktu penyediaan linen. Hasil studi pendahuluan di BLUD RS Sekarwangi ditemukan bahwa pencapaian Standar Pelayanan Minimal tahun 2017 mencapai nilai rerata $100 \%$.

Hasil penelitian pendahuluan ditemukan infeksi daerah operasi pada bulan September - November tahun 2016 rata - rata secara keseluruhan adalah 5.2\% dari total 326 operasi Sectio Cesaria (SC). Bila dilihat perbulan maka insiden IDO berkisar antara 4.2 - 6.0\%. Pada bulan September - November tahun 2017 rata- rata secara keseluruhan angka kejadian infeksi daerah operasi adalah $16.5 \%$ dari total 310 operasi Sectio Cesaria (SC). Bila dilihat perbulan maka insiden IDO berkisar antara 8.9 - 20.4\%. Angka ini lebih tinggi bila dibanding dengan kejadian IDO di RSCM pada tahun 2016 yaitu berkisar antara $0.27-0.99 \%$.

Sebagai rumah sakit tipe B dan merupakan Rumah Sakit BLUD diharapkan dapat meningkatkan pelayanan yang berbasis patient safety dimana safety untuk untuk pasien, safety untuk petugas kesehatan, safety untuk institusinya, safety untuk lingkungannya dan 
juga safety untuk business. Berdasarkan hasil studi pendahuluan pada bulan April - Juli 2018 di BLUD RS Sekarwangi, standar linen dan laundry di BLUD RS Sekarwangi belum semua dapat dilakukan dengan optimal, baik dalam memenuhi kebutuhan linen sampai pencucian dan distribusi serta prosedur yang bisa berdampak pada peningkatan infeksi nosokomial, seperti dalam proses pengumpulan linen kotor di ruangan (Rawat Inap, IGD, IBS, ICU dan Poliklinik) masih ada ruangan yang tidak melakukan pemisahan linen kotor infeksius dan linen kotor non infeksius, masih ditemukan ember pengumpulan linen kotor infeksius dan non infeksius yang tidak tertutup. Linen kotor tidak di masukkan ke dalam plastik terlebih dahulu akan tetapi langsung di masukkan ke dalam ember pengumpulan linen kotor, pengambilan linen kotor infeksius dan non infeksius diruangan dalam satu trolly, kuranganya kesadaran akan hygiene pada petugas, faktor noda yang tidak hilang maupun perubahan warna pada linen. Penempatan SDM yang tidak tepat juga menjadi salah satu masalah dalam pengelolaan linen.

Dengan berbagai permasalahan yang terjadi pada instalasi laundry di BLUD RS Sekarwangi diperlukan standard atau prosedur, lokasi, perencanaan, pengelolaan dan distribusi serta penempatan SDM yang tepat di instalasi laundry dan manajemen laundry untuk meningkatkan mutu layanan instalasi laundry, baik dalam komunikasi yang sinergis antar staf laundry dengan perawat ruangan dan penghargaan seperti piagam, pelatihan. Berdasarkan latar belakang dan berbagai uraian yang tersebut, peneliti menilai bahwa perbaikan dalam proses pengelolaan linen di rumah sakit penting untuk dilakukan.

\section{METODE}

Desain penelitian yang digunakan adalah kualitatif. Penelitian dilakukan di BLUD RS Sekarwangi pada April-Juni 2018. Informan penelitian ini ditentukan berdasarkan purposive sampling. Pengumpulan data dengan metode wawancara mendalam, focus grup discussion, observasi dan telaah dokumen. Variabel yang diteliti meliputi input (tenaga, pendanaan, sarana prasarana, dan kebijakan) process (pengumpulan, penerimaan, pencucian, pengeringan, penyetrikaan, pendistribusian) dan output (pengelolaan linen sudah sesuai standar atau belum). Pengolahan data dilakukan dengan metode reduksi data, penyajian data, penarikan kesimpulan dan analisis data menggunakan teknik analisis isi dengan triangulasi sumber dan triangulasi metoda.

\section{HASIL}

Karakteristik SDM di instalasi laundry BLUD RS Sekarwangi 100\% telah sesuai dengan standar, berdasarkan batas usia telah sesuai dengan standar, latar belakang 
pendidikan petugas instalasi laundry telah sesuai standar karena saat ini instalasi laundry di pimpin oleh seorang perawat atau tenaga kesehatan dan semua petugas instalasi laundry telah mendapatkan pelatihan pengelolaan linen. Jamilatus dkk (2015) kualifikasi petugas laundry dan linen yang belum memenuhi standar menyebabkan petugas kurang paham mengenai manajemen linen. Batas umur, latar belakang pendidikan, pelatihan dan masa kerja sangat berpengaruh terhadap keterampilan dalam pengelolaan linen. Pada kenyataannya situasi di lapangan di instalasi laundry di BLUD RS Sekarwangi tidak sesuai dengan teori yang seharusnya. Hal ini terlihat dari masa kerja yang lebih dari $>10$ tahun tidak menyebabkan petugas lebih berhati-hati dan mengikuti SPO dan peraturanperaturan yang ada untuk melindungi mereka dari kemungkinan penularan penyakit dan kecelakaan kerja yang dapat terjadi sewaktu-waktu.

Berdasarkan hasil wawancara, observasi, telaah dokumen dan kuesioner didapatkan 26.2\% sarana dan prasarana di instalasi laundry BLUD RS Sekarwangi belum memenuhi standar. Menurut Depkes RI (2004) sarana prasarana yang diperlukan dalam pelaksanaan pengelolaan linen di unit laundry antara lain: ruangan penerimaan linen, ruang pemisahan linen, ruang pencucian dan pengeringan linen, ruang penyetrikaan dan pelipatan linen, ruang penyimpanan linen, ruang distribusi linen, ruang dekontaminasi troli, meja penerima linen infeksius dan non infeksius, meja untuk mensortir linen non infeksius, meja administrasi, meja penyerahan linen bersih, timbangan duduk, troli , mesin cuci, mesin pengering, mesin penyetrika, mesin penyetrika pres, mesin jahit, lemari penyimpanan linen, prasarana listrik, prasarana uap, prasarana air bersih, detergen, desinfektan/bleach, plembut, emulsifier, penetral, alkali, kanji. Selain itu bagian laundry juga harus mempunyai ruang dekontaminasi/perendaman linen, kamar mandi, petugas, gudang bahan kimia, ruang penyimpanan trolly bersih, nak pembilas awal, bak perendaman dan bak pembilas akhir yang digunakan untuk dekontaminasi lienen sebelum proses pencucian. Kurang lengkapnya atau bila terdapat ketidaksesuaian pada sarana dan prasarana penunjang pengelolaan linen di instalasi laundry dapat mempengaruhi efisiensi dan produktivitas kerja serta pelayanan di instalasi tersebut.

Berdasarkan hasil wawancara, observasi, telaah dokumen dan kuesioner didapatkan 5.3\% konstruksi ruang dan bangun ruang di instalasi laundry belum sesuai dengan pedoman manajemen linen yaitu pertemuan dinding dengan lantai berbentuk tajam serta lemari penyimpanan linen terbuka. Mentari Mangesti dkk (2016) bagian fisik laundry yang belum sesuai standar dapat mengganggu proses pengelolaan linen, sehingga pengelolaan linen tidak dapat berjalan dengan baik dan sesuai yang ditargetkan. 
H. Djadjang A, Teguh Wiyono, Dini Agustiani : Analysis of the Flow Process ...

Berdasarkan hasil wawancara, observasi dan telaah dokumen ditemukan 23.8\% belum sesuai dengan pedoman manajemen linen yaitu letaknya berjauhan dengan CSSD, tidak ada pengolahan untuk limbah laundry sebelum dialirkan ke IPAL serta belum dilakukannya perawatan berkala pada mesin. Berdasarkan hasil penelitian, air limbah yang dihasilkan dari proses pencucian di instalasi laundry langsung dialirkan ke instalasi pembuangan air limbah (IPAL) rumah sakit tanpa adanya pengolahan awal. Hal tersebut tidak sesuai dengan Kepmenkes No. 1204 tahun 2004 yang menyatakan bahwa laundry rumah sakit harus melakukan pengolahan awal (pre-treatment) air limbah sebelum dialirkan pada instalasi pengolahan air limbah.

Berdasarkan hasil wawancara, observasi dan telaah dokumen didapatkan 11\% hygiene petugas dalam kepatuhan mencuci tangan belum sesuai dengan standar. Salah satu faktor yang dapat membantu melindungi dan mencegah terjadinya infeksi nosokomial pada petugas dan pengelola linen baik di instalasi laundry maupun di ruangan adalah melalui personal hygiene yang baik. Personal hygiene yang perlu diperhatikan pada petugas dan pengelola linen yaitu meliputi kegiatan mencuci tangan, penyakit kulit, pemeriksaan kesehatan dan pemberian imunisasi pada petugas.

Menurut Fijan, S (2000) salah satu upaya penting yang dapat dilakukan oleh petugas dalam mencegah terjadinya penyebaran mikroorganisme adalah melalui kebersihan petugas itu sendiri. Salah satu hal yang dapat dilakukan antara lain membiasakan mencuci tangan sebelum dan sesudah melakukan pekerjaan. Hasil penelitian kepada petugas dan pengelola linen di instalasi laundry diketahui bahwa tidak semua petugas membiasakan diri untuk mencuci tangan sebelum dan sesudah melakukan proses pengelolaan linen. Hal ini tidak sesuai dengan standar prosedur operasional pengelolaan linen BLUD RS Sekarwangi, yang menyatakan bahwa petugas melakukan cuci tangan sebelum dan sesudah melakukan pengelolaan linen.

Menurut Depkes RI (2004), petugas pengelola linen di ruangan harus membiasakan mencuci tangan higienis dengan sabun minimal 10-15 detik sebelum dan sesudah melakukan pekerjaan. Dengan mencuci tangan seorang petugas pengelola linen dapat mengurangi penyebaran bakteri atau virus dari tubuh petugas ke linen bersih dan tangan petugas yang kotor atau terkontaminasi juga dapat mengacam kesehatan petugas itu sendiri.

Penelitian ini tidak sesuai dengan Kepmenkes No 1204 tahun 2004 Tentang Persyaratan Kesehatan Lingkungan Rumah Sakit yaitu pada bagian laundry untuk petugas pencucian linen dilakukan pemeriksaan kesehatan berkala, serta dianjurkan memperoleh 
imunisasi hepatitis B. namun dari pihak manajemen rumah sakit untuk pemberian imunisasi hepatitis B sudah dalam perencanaan dan akan dilaksanakan dalam waktu dekat.

Berdasarkan hasil observasi ketersediaan dan penggunaan APD di instalasi laundry didapatkan $11 \%$ belum sesuai standar dikarenakan masih ada petugas linen di instalasi laundry maupun di ruangan tidak mengenakan APD lengkap sesuai dengan tugasnya pada saat pengelolaan linen. Penelitian ini tidak sesuai dengan keputusan menteri kesehatan no 1204 tahun 2004 Tentang Persyaratan Kesehatan Lingkungan Rumah Sakit yaitu pada bagian laundry untuk petugas pencucian linen laundry harus menggunakan pakaian kerja khusus, alat pelindung diri (APD). Mentari Mungesti dkk (2016) pemakaian APD oleh petugas pengelolaan linen pada bagian laundry di RSPAU DR. Suhardi Hardjolukito tidak lengkap sehingga tidak memenuhu syarat sesuai dengan standar operasional prosedur (SOP). Petugas harus memakai APD secara lengkap pada saat melakukan pengelolaan linen agar melindungi petugas dari sumber resiko kecelakaan atau penyakit akibat kerja.

Berdasarkan hasil wawancara, observasi dan telaah dokumen ditemukan $50 \%$ pengelolaan linen di ruangan belum sesuai standar yaitu belum semua ruangan memisahkan antara linen infeksius dan non infeksius mulai dari sumbernya, pengumpulan linen infeksius dan non infeksius tidak dimasukan kedalam kantung terlebih dahulu akan tetapi langsung dimasukan ke dalam ember, tidak semua ruangan membuang feses, muntahan/noda darah yang masih menempel dan membasahinya dengan air, hampir semua ruangan tidak menghitung dan mencatat linen kotor di ruangan, tidak Dilakukan penutupan kantung/penyegelan, tidak dilakukan labeling pada kantung. Hal ini tentu belum sesuai dengan pedoman manajemen linen sehingga perlu ditekankan kembali SOP pengelolaan linen. Mentari Mangesti (2016) proses pengumpulan linen dari bangsal RSPAU DR. Suhardi Hardjolukito tidak dilakukan pemasukan linen kotor ke dalam kantung plastic tetapi langsung ke bak kereta yang sesuai jenisnya.

Pengelolaan linen di ruangan BLUD RS Sekarwangi tidak sesuai standar peraturan Kepmenkes RI No.1204 tahun 2004 tentang persyaratan kesehatan lingkungan rumah sakit, yang menyatakan bahwa pada saat pengumpulan linen dilakukan pemilahan linen infeksius dan non infeksius dimulai dari sumbernya dan memasukkan linen ke dalam kantong plastik sesuai dengan jenisnya. Penyediaan kantong plastik untuk mengumpulkan linen kotor sangat membantu dalam mengurangi penyebaran kuman (Depkes RI, 2000). 
H. Djadjang A, Teguh Wiyono, Dini Agustiani : Analysis of the Flow Process ...

Kepmenkes RI No. 1204 tahun 2004 juga menganjurkan untuk memberi label pada kantong plastik infeksius maupun non infeksius, namun berdasarkan hasil penelitian tidak dilakukan pemberian label pada kantong linen infeksius maupun non infeksius. Pemberian label pada kantong plastik berfungsi untuk mempermudah mengenali jenis linen yang berada dalam kantong tersebut dan untuk mencegah terjadinya kekeliruan penggunaan kantong plastic. Berdasarkan hasil observasi ditemukan 90\% linen sesuai standar namun untuk pemeriksaan bakteriologik linen belum pernah dilakukan. Pemeriksaan ini penting dilakukan untuk mengetahui dan memantau kualitas linen yang dihasilkan

Berdasarkan hasil observasi penanganan linen di instalasi laundry ditemukan 50\% belum sesuai dengan standar pedoman manajemen linen. Suparno (2018) aspek input kebijakan sudah ada, tenaga dan pendanaan belum mencukupi, untuk sarana prasarana belum sesuai standar Kepmenkes. Aspek process tahap pengumpulan belum memisahkan linen infeksius dan non infeksius dan belum ada pencatatan, tahap penerimaan belum ada pencatatan dan linen belum di pisahkan, tahap pencucian tidak adanya penimbangan dan tidak dilakukan desinfeksi karena tidak adanya desinfektan dan air panas $70^{\circ} \mathrm{C}$, tahapan pengeringan menggunakan mesin pengering tetapi linen bersih masih kontak dengan petugas cuci, tahap penyetrikaan linen tidak dilakukan karena alat rusak, pintu lemari tidak selalu tertutup pada tahap penyimpanan, pendistribusian menggunakan troli yang berbeda dengan linen kotor tetapi tidak tertutup.

Pengelolaan linen yang tidak sesuai dengan standar menimbulkan dampak negative bagi pasien maupun petugas pengelola linen. Dalam memudahkan proses pencucian linen salah satu metode yang harus dilakukan adalah melakukan proses pemilahan linen terlebih dahulu. Berdasarkan hasil penelitian diketahui proses pemilahan linen di instalasi laundry BLUD RS Sekarwangi dibedakan berdasarkan linen infeksius dan linen non infeksius. Pada tahap ini seharusnya tidak dilakukan pembongkaran muatan untuk menyortir linen infeksius namun ternyata hal ini masih dilakukan oleh sebagian petugas di instalasi laundry. Hal ini tidak sesuai dengan Depkes RI (2004), yang menyatakan bahwa pensortiran untuk linen infeksius sangat tidak dianjurkan, penggunaan kantong sejak dari ruangan adalah salah satu upaya untuk menghindari sortir. Penyortiran linen infeksius membuat petugas terkontaminasi dan dapat pula menjadi sumber kontaminasi linen bersih (Depkes RI, 2000).

Selain pemilahan berdasarkan linen infeksius dan dan linen non infeksius, juga dilakukan pemilahan berdasarkan warna linen (Depkes RI, 2004). Menurut Kepmenkes 
RI No. 1204 tahun 2004, sebelum dilakukan proses pencucian, linen kotor juga harus dipilah berdasarkan tingkat kekotoran. Berdasarkan hasil penelitian yang telah dilakukan di instalasi laundry BLUD RS Sekarwangi, pada tahap pemilahan linen sudah dilakukan pemilahan berdasarkan tingkat kekotorannya namun pemilahan berdasarkan warna belum dilakukan. Hal ini tidak sesuai dengan peraturan yang ditetapkan dalam Kepmenkes RI No. 1204 tahun 2004 tentang Persyaratan Kesehatan Lingkungan Rumah Sakit. Proses pemilahan yang sesuai dengan peraturan yang ditetapkan dapat membantu mempermudah petugas dalam proses pencucian linen.

\section{SIMPULAN}

Analisis pengelolaan linen kotor di Instalasi Laundry BLUD RS Sekarwangi memiliki Karakteristik SDM sebanyak 100\% sesuai dengan standar manajemen linen, Sarana dan Prasarana sebanyak 26\% belum sesuai dengan pedoman manajemen linen,beberapa bagian ruangan yang belum memenuhi standar pada ruang pemisahan linen, ruang penyetrikaan dan penyimpanan linen menjadi satu, tidak ada meja penerimaan, meja pemisahan, meja distribusi linen tidak digunakan, belum ada ruang khusus dekontaminasi troli, bak pembilasan awal, bak pembilasan akhir, emulsifier, penetral, starch/ kanji, kategori pencahayaan, kategori suhu ruangan dan kelembaban, Konstruksi ruang dan bangunan 5.3 \% belum sesuai dengan pedoman manajemen linen Kondisi konstruksi dan bangunan instalasi laundry BLUD RS Sekarwangi masih belum termasuk dalam kategori baik dikarenakan masih terdapat hal-hal yang belum sesuai standar seperti pertemuan lantai dan dinding yang berbentuk tajam, pintu dari kaca aluminium hanya saja sering dalam keadaan terbuka, Hygiene petugas $75 \%$ belum sesuai pedoman manajemen linen dikarenakan belum semua petugas pengelola linen membiasakan diri untuk mencuci tangan sebelum dan sesudah melakukan proses pengelolaan linen dan tidak semua petugas pengelola linen mendapatkan imunisasi Hepatitis B. Pemeriksaaan kesehatan berkala juga tidak dilakukan manajemen rumah sakit terhadap petugas pengelola linen. Namun saat ini dalam waktu dekat akan dilakukan pemberian imunisasi hepatitis B untuk petugas BLUD RS Sekarwangi tidak terkecuali unit laundry, Kelengkapan APD 100\% namun kepatuhan $11 \%$ yang belum sesuai standar pedoman manajemen linen, Pengelolaan linen diruangan 50\% belum sesuai standar manajemen linen dan Pengelolaan linen di instalasi laundry 50\% belum sesuai standar. Proses pengelolaan linen di ruangan dan di instalasi laundry masih belum baik. Diketahui masih terdapat hal-hal yang belum memenuhi standar pedoman pengelolaan linen yang 
baik pada pengelolaan linen di ruangan maupun di instalasi laundry, pengolahan limbah tidak dilakukan pengolahan awal/pre treatment di bagian laundry sebelum di alirkan ke Instalasi Pembuangan Air Limbah (IPAL), Linen dan bed cover yang sudah bersih di kemas dengan plastik bening dan disimpan sesuai nama ruangan dilemari penyimpanan. Dimana tempat penyimpanan linen berupa rak terbuka sehingga mudah terkontaminasi udara sekitar. Pengawasan kualitas fisik dilakukan secara rutin namun untuk pemeriksaan bakteriologis linen non steril belum pernah dilakukan Kualitas linen bersih yang meliputi kondisi fisik linen bersih diinstalasi laundry hanya 90 \% yang berada dalam kondisi baik (tidak berbau, lembut dikulit, tidak bernoda, warna tidak pudar dan awet (tidak mudah rapuh). Adapun pemeriksaan angka bakteriologis belum pernah dilakukan, Monitoring dan evaluasi 50\% menyatakan ragu-ragu dengan kualitas linen bersih non steril dan 12,5 \% menyatakan tidak puas dengan pelayanan petugas linen, sedangkan alur proses pengelolaan linen bersih di BLUD RS Sekarwangi mulai dari perencanaan, pengadaan, pemberian identitas, distribusi, penerimaan, pencatatan dan pelaporan, proses pengelolaan linen kotor hingga menjadi linen bersih di instalasi laundry kemudian didistribusikan ke ruangan 1 kali dalam sehari yaitu pada jam 13.00 siang hari

\section{UCAPAN TERIMA KASIH}

drg. Sri Rahayu, MARS, Ph.D selaku Ketua Program Pascasarjana Program Studi Administrasi Rumah Sakit Universitas Respati Indonesia (URINDO) yang telah memberikan kesempatan kepada saya untuk menempuh pendidikan. DR. R. H. Djadjang A, SH, MKes dan Teguh Wiyono, SE, MARS sebagai pembimbing yang telah banyak memberikan masukan dan arahan yang bermanfaat dalam penyusunan tesis ini.

\section{DAFTAR PUSTAKA}

Adisasmito, 2007, Sistem Manajemen Lingkungan Rumah Sakit, Raja Grafindo Persada, Jakarta

Aisyah, Prijono, 2013. Surveilans Infeksi Daerah Operasi (IDO) Menurut Komponen Surveilans di Rumah Sakit X Surabaya Tahun 2012. Journal Berkala Epidemiologi:1(2); 254-265.

Burhan Bungin, 2001. Metodologi Penelitian Kualitatif, edisi satu, Jakarta: RajawaliPers. CDC., 2013. The Burden. http://www.cdc.gov/HAI/burden.html. (sitasi tanggal 16 Desember 2016 pukul 19.20)

Dashiell, S. 2014. Infection control: Oversee cleaning of linens and protect from contamination to avoid costly infections. Environment of Care Leader: 9 (11);1-6.

Depkes RI, 2004. Pedoman Manajemen Linen di Rumah Sakit, Direktorat Jendral Pelayanan Medik, Jakarta.

Depkes RI, 2004. Keputusan Menteri Kesehatan RI No. 1204/Menkes/SK/X/2004 tentang Persyaratan Kesehatan Lingkungan Rumah Sakit, Jakarta. 
Depkes RI, 2009. Pedoman Instalasi Pusat Sterilisasi (Central Sterile Supply Department/ CSSD) di Rumah Sakit, Jakarta

Depkes RI, 2010. Pedoman Teknis Sarana dan Prasarana Rumah Sakit B, Sekretariat Jendral Pusat Sarana, Prasarana dan Peralatan Kesehatan, Jakarta.

Djojodibroto,D. 1997. Kiat Mengelola Rumah Sakit. Jakarta: Hipokrates.Esei et al. 2002. Polymicrobial Ventriculitis and Evaluation of an Outbreak in a Surgical Intensive Care Unit due to Inadequate Sterilization.

Fitriasari N, Haryanti T, Yuliansyah N. Sistem Pengawasan dan Pengendalian Linen sebagai Startegi Mengurangi Angka Linen Hilang. Jurnal Kedokteran Brawijaya. 2016;Vo.29 No.3(Malang):279-84.

Lemass, $\mathrm{H}$ et al. 2013. Infection Prevention and Control for Primary Care in Ireland: A guide for General Practice. Ireland: HCAI.

Munijaya. Manajemen Kesehatan. Jakarta: EGC; 2004.

Mungesti, Mentari, dkk. 2016. Gambaran Pengelolaan Linen di Bagian Laundry RSPAU Dr. Suhardi Hardjolukito Yogyakarta; hal 205-214. Pada Majalah Ilmu Kesehatan dan Keperawatan Indonesia vol. 4, No.1.

Muri, 2014. Metode Penelitian Kuantitatif, Kualitatif dan Penelitian Gabungan. Jakarta: Prenadamedia Group

Nauli M. Analisis Pengelolaan Linen Laundry di Rumah Sakit Umum X kota Medan Tahun 2015 (SKRIPSI): Universitas Sumatera Utara; 2015.

Nur Aini, Muhamad, dkk. 2013. Analisis Pengelolaan Linen di Instalasi Rawat Inap RS Permata Bunda Purwodadi (Studi Kualitatif); hal 197-205. Pada Jurnal Manajemen Kesehatan Indonesia Vol.1, No.3.

Prajitno S. Dasar-dasar Administrasi Kesehatan Masyarakat. Surabaya: Airlangga Press; 2008.

Punit Yadav, dkk. 2016. Quality assurance in hospital linen and laundry services; Page 11411-11413. In Int. J. of Recent Scientific Research 7, No. 5.

Syamsiah A, Jamilatus, dkk. 2015. Peningkatan Mutu RSI Unisma Malang Melalui Reformasi Manajemen Laundry dan Linen; hal 148-152. Pada Jurnal Kedokteran Brawijaya, Vol. 28, Suplemen No. 2.

Sri Lestari, Feronika, dan Mahawati, Eni. 2010. Faktor-Faktor yang Berhubungan dengan Praktek Pengelolaan Linen oleh Perawat di Ruang Rawat Inap RSUD Kota Semarang 2010. Pada Jurnal Visikes, Vol.9 No.1.

Sugiyono. 2016. Metode Penelitian Kuantitatif, Kualitatif dan R\&D. cetakan ke 24. Bandung: Alfabeta.

Suparno, 2018. Analisis Manajemen Pengelolaan IInen Di Instalasi Laundry RSUD Kota Dumai 2017. Pada Jurnal FKM Andalas

Soekidjo Notoatmojo. 2012. Metodologi Penelitian Kesehatan. Jakarta: Rineka Cipta.

TRSA, 2016. Standard for Producing Hygienically Clean Reusable Textiles for Use in the Healthcare Industry. http://www.trsa.org/ ( sitasi tanggal 16 Desember 22.00)

Tietjen, et al.2004. Panduan Pencegahan Infeksi untuk Fasilitas Pelayanan Kesehatan dengan Sumber Daya Terbatas. Jakarta: Yayasan Bina Pustaka Sarwono Prawirohardjo.

Undang-undang Republik Indonesia Nomor 44 Tahun 2009 tentang Rumah Sakit.

Wijono, D.2000. Manajemen Mutu Pelayanan Kesehatan Teori, Strategi dan Aplikasi. Surabaya: Airlangga University Press.

WHO, 2002. Guidelines on Prevention and Control of Hospital Associated Infections. https://www.google.co.id/url?sa=t\&source=web\&rct=j\&url=http://apps.searo.who. int/PDS DOCS/B0007.pdf (sitasi tanggal 16 Desember 2016 pukul 21.00) 